\title{
STUDI PERBANDINGAN PERSEPSI PERAWAT DAN PEGAWAI PEMERINTAH DAERAH TENTANG KEPUTUSAN MENTERI KESEHATAN REPUBLIK INDONESIA NO 1239/MENKES/SK/XI/2001 SEBAGAI DASAR HUKUM PRAKTIK KEPERAWATAN PADA LINGKUP OTONOMI DAERAH
}

\section{Comparative Study Perception of Nurses and Local Government Officials of The Minister of Health of The Republic of Indonesia No 1239 / Menkes / Sk / Xi / 2001 As A Basis For Nursing Practice Law In The Scope of Regional Autonomy}

\author{
Muhammad Rakip Latuconsina ${ }^{1}$, Nursalam ${ }^{2}$, Kusnanto ${ }^{3}$ \\ ${ }^{1)}$ Kepala Bidang Keperawatan Rumah Sakit Umum Daerah (RSUD) Masohi \\ Jl. Dr. GA. Siwabessy No 18 Maluku Tengah 51791 \\ ${ }^{2,}{ }^{3}$ Fakultas Keperawatan Universitas Airlangga Surabaya
}

\begin{abstract}
ABSTRAK
Praktik keperawatan yang tertuang dalam Keputusan Menteri Kesehatan RI No 1239/MenKes/SK/XI/ 2001 sebagai dasar hukum praktik keperawatan Bab 4 pasal 17 berisi tentang perawat dalam melaksanakan praktik harus sesuai dengan kewenangan yang diberikan berdasarkan pendidikan dan pengalaman serta dalam memberikan pelayanan berkewajiban mematuhi standar profesi. Tujuan dari penelitian ini adalah untuk mengetahui perbandingan persepsi perawat dan pegawai pemerintah daerah tentang Keputusan Menteri Kesehatan RI No 1239/MenKes/SK/XI/2001 sebagai dasar hukum praktik keperawatan pada lingkup otonomi daerah. Desain penelitian yang digunakan adalah studi komparatif, sampel yang diambil 50 responden, menggunakan teknik pusposive sampling, analisa data dengan signifikansi $p<0,05$. Hasil penelitian didapatkan dengan uji statistik chi-square $\mathrm{p}=0,00$ yang berarti ada perbedaan persepsi perawat dan pegawai pemerintah daerah. Perbedaan hasil analisa dapat disimpulkan bahwa perbedaan perawat dan pegawai pemerintah daerah disebabkan karena kurangnya sosialisasi. Untuk itu informasi tentang praktik keperawatan harus disosialisasikan lebih luas dan lebih optimal di dalam organisasi profesi (Persatuan Perawat Nasional Indonesia/PPNI), jajaran pemerintah daerah maupun pada masyarakat luas.
\end{abstract}

Kata kunci: KepMenKes RI No 1239/MenKes/SK/XI/2001, persepsi perawat, persepsi pegawai pemerintah daerah

\begin{abstract}
Nursing practice is based on KepMenKes RI No 1239/KepMenKes/SK/XI/2001 article four section 17 as the legal base for nursing practice. Nursing should be practiced according to designated authority, which is based on education and experience, and in providing their service they have to obey professional standard. However, in practice, there is no nurse who has license (SIP, SIK, and SIPP) in performing their professional practice. This might be due to dissimilar information between nurses and local government officers. The objective of this study was to find the difference of the perception in nurses and local government officers on KepMenKes RI No 1239/KepMenKes/SK/XI/2001 as the legal base for nursing practice under the scope of regional autonomy. This study was a comparative study. Samples involved comprised 50 respondents, recruited using purposive sampling method. Data analysis had significance level of $p<$ 0,05. Using Chi-square test, it was found that $p=0,00$, indicating difference between the perception of nurse and that of local government officers on. Therefore, information on nursing practice should be socialized widely and optimally, particularly within profession organization (Indonesian Nurse Organization/PPNI), local government officers, and the society.
\end{abstract}

Keywords: KepMenKes RI No 1239/KepMenKes/SK/XI/2001, nurse's perception, local government officer's perception 


\section{LATAR BELAKANG}

Upaya menghadapi tuntutan kebutuhan masyarakat di masa mendatang maka langkah konkrit yang harus dilakukan antara lain adalah penataan standar praktik dan standar pelayanan/asuhan keperawatan sebagai landasan pengendalian mutu pelayanan keperawatan secara profesional. Munculnya Keputusan Menteri Kesehatan (KepMenKes) RI No 1239/MenKes/SK/XI/ 2001 sebagai dasar hukum praktik keperawatan profesional, ternyata menimbulkan kontroversi antara pemerintah daerah dan dinas kesehatan. Dimana perawat melakukan praktik keperawatan yang birokrasinya harus mendapat ijin dari instansi terkait, dalam hal ini pemerintah daerah sesuai dengan UU No 22/1999 tentang otonomi daerah, sedangkan persepsi pegawai pemerintah daerah itu sendiri kurang memahami dan mengerti akan kewenangan perawat dalam melakukan praktik keperawatan, apakah ini diperbolehkan atau tidak. Persepsi inilah yang nantinya dapat mempengaruhi pemahaman masyarakat. Mengacu pada Undang-Undang Kesehatan no 23 tahun 1992 pasal 53 (ayat 1 dan 2) bahwa tenaga kesehatan berhak memperoleh perlindungan hukum dalam melaksanakan tugas sesuai dengan profesi dan tenaga kesehatan dalam melakukan tugasnya berkewajiban untuk mematuhi standart profesi dan menghormati hak pasien. Selanjutnya ditegaskan pula dalam PP no 32 tahun 1996 pasal 21 tentang tenaga kesehatan bahwa setiap tenaga kesehatan dalam melakukan tugasnya berkewajiban untuk mematuhi standart profesi tenaga kesehatan.

Bertolak pada hal-hal tersebut di atas maka dalam melaksanakan tindakan mandiri keperawatan profesional perawat dituntut untuk selalu melaksanakan asuhan keperawatan dengan benar sesuai kaidah ilmiah yang baik atau sesuai etika keperawatan. Untuk menjamin perlindungan terhadap masyarakat penerima pelayanan dan asuhan keperawatan serta perawat sebagai pemberi pelayanan dan asuhan keperawatan, maka diperlukan ketetapan hukum yang mengatur praktik keperawatan yaitu tentang registrasi dan praktik keperawatan yang telah diterbitkan oleh pemerintah pada tanggal 22 November 2001 yang disebut KepMenKes RI No 1239/MenKes/SK/XI/2001. Dampak dari tidak adanya suatu landasan hukum bagi pelaksanaan praktik keperawatan dapat memperburuk sistim pelayanan keperawatan yang merupakan bagian integral dari pelayanan kesehatan. Dimana praktik tidak dilaksanakan sesuai dengan prosedur dan mekanisme kerja yang baik serta kurang memahami aturan main dari landasan hukum tersebut. Untuk itu diperlukan sosialisasi kebijakan tersebut kepada pegawai pemerintah pada umumnya dan tenaga keperawatan khususnya sehingga perbedaan persepsi dapat dihindari.

Praktik keperawatan profesional yang tertuang pada KepMenKes RI No 1239/ MenKes/SK/XI/2001 dalam bab 4 pasal 17 adalah perawat dalam melaksanakan praktik keperawatan harus sesuai dengan kewenangan yang diberikan berdasarkan pendidikan dan pengalaman serta dalam memberikan pelayanan berkewajiban mematuhi standar profesi. Namun pada kenyataannya keperawatan di Indonesia hingga saat ini masih belum mencerminkan sepenuhnya keperawatan sebagai suatu profesi. Hasil pengamatan mengindikasikan bahwa pihak terkait seperti pegawai pemerintah kurang memahami tentang KepMenKes RI No 1239/MenKes/SK/XI/ 200 sebagai dasar hukum praktik keperawatan serta kurangnya pengaruh organisasi profesi PPNI dalam mensosialisasikan KepMenKes RI No 1239/ MenKes/SK/XI/2001 kepada pemerintah daerah setempat.

Memperhatikan kondisi tersebut di atas bahwa pemberlakuan KepMenKes RI No 1239/MenKes/SK/XI/2001 sangat penting, Oleh karena itu dalam pelaksanaannya 
diperlukan pemahaman dan dukungan dari berbagai pihak yang terkait. Sebagai upaya menyamakan persepsi terhadap pemahaman isi dan makna KepMenKes RI No 1239/ MenKes/SK/XI/2001 tersebut khususnya kepada tenaga keperawatan organisasi profesi PPNI maka perlu melakukan sosialisasi atau desiminasi menggunakan hirarki organisasi yaitu pengurus pusat ke pengurus propinsi dan selanjutnya diteruskan kepengurus kabupaten kota sampai ke tingkat komisariat. Namun dalam kenyataan di masyarakat Kabupaten Maluku Tengah fenomena menunjukkan belum adanya pemahaman dan persepsi yang sama dari tenaga kesehatan (perawat) dan pegawai pemerintah yang terkait dengan praktik keperawatan dan isi serta KepMenKes RI No 1239/MenKes/SK/XI/2001, maka untuk mendapatkan pemahaman dan persepsi yang sama perlu dilakukan suatu kajian terhadap masalah tersebut di atas.

\section{METODE}

Penelitian studi komparatif dengan desain difokuskan untuk mengkaji perbandingan terhadap pengaruh (efek) pada kelompok subjek tanpa adanya suatu perlakuan/rekayasa dari peneliti.

Penelitian yang dilakukan di Masohi Kabupaten Maluku Tengah Provinsi Maluku sejak 1-31 Januari 2005 dengan populasi adalah semua perawat yang melaksanakan praktik keperawatan dan pegawai pemerintah yang bekerja pada instansi pemerintahan yaitu PNS DPK, PNS DPB, dan PNS Daerah yang diseleksi dengan menggunakan purposive sampling dengan kriteria inklusi perawat: semua perawat yang melaksanakan praktik keperawatan dengan jenjang pendidikan SPK, D III keperawatan dan S1 keperawatan; usia di atas 25 tahun; sehat jasmani dan rohani; masa kerja minimal 2 tahun. Kriteria inklusi pegawai pemerintah: pegawai pemerintah daerah; usia di atas 25 tahun; sehat jasmani dan rohani; masa kerja minimal 2 tahun. Instrumen pengumpulan data yang digunakan berbentuk checklist, kuisioner dan observasi mengenai kemampuan perawat, karakteristik individu dalam memahami masalah hukum praktik keperawatan dalam otonomisasi daerah. Kemudian data yang terkumpul ditabulasi dan dianalisis dengan menggunakan uji statistik chi-square.

\section{HASIL DAN PEMBAHASAN}

\section{Persepsi Perawat}

Hasil penelitian mengenai persepsi perawat terhadap berlakunya KepMenKes RI No 1239/MenKes/ SK/XI/2001 sebagai dasar hukum praktik keperawatan disajikan pada tabel 1 .

Tabel 1. Persepsi perawat terhadap berlakunya KepMenKes RI No 1239/MenKes/ SK/XI/2001 sebagai dasar hukum praktik keperawatan.

\begin{tabular}{cc}
\hline \multicolumn{2}{c}{ Persepsi perawat } \\
\hline Pernyataan & Jumlah \\
Benar & 24 responden \\
Salah & 1 responden \\
\hline & \\
\hline \multicolumn{2}{c}{ Mean $=1,96$} \\
SD $=0,20$ \\
Signifikansi $(\mathrm{p})=0,000$ \\
\hline
\end{tabular}

Dari tabel 1 diketahui hasil uji statistik chi-square yaitu nilai rata-rata $($ Mean $=1,96)$ ini berarti sebagian besar responden memiliki persepsi yang benar yaitu dengan signifikansi $(\mathrm{p})=0,000$.

\section{Persepsi Pegawai Pemerintah Daerah}

Hasil penelitian mengenai persepsi pegawai pemda terhadap berlakunya KepMenKes RI No 1239/MenKes/ SK/XI/ 2001 sebagai dasar hukum praktik keperawatan disajikan pada tabel 2. 
Tabel 2. Persepsi pegawai pemda terhadap berlakunya KepMenKes RI No 1239/MenKes/SK/XI/2001 sebagai dasar hukum praktik keperawatan.

\begin{tabular}{cc}
\hline \multicolumn{2}{c}{ Persepsi pegawai pemda } \\
\hline $\begin{array}{c}\text { Pernyataan } \\
\text { Benar }\end{array}$ & $\begin{array}{c}\text { Jumlah } \\
\text { 20 responden }\end{array}$ \\
Salah & 5 responden \\
& \\
\multicolumn{2}{c}{ Mean $=1,80$} \\
SD $=0,40$ \\
Signifikansi $(\mathrm{p})=0,003$
\end{tabular}

Dari tabel 2 diketahui hasil uji statistik chi-square yaitu nilai rata-rata $($ Mean $=1,80)$ ini berarti sebagian besar responden memiliki persepsi yang benar yaitu dengan signifikansi $(p)=0,003$.

\section{Persepsi Perawat Dan Pegawai Pemerintah Daerah}

Hasil penelitian tentang perbandingan persepsi perawat dan pegawai pemda terhadap berlakunya KepMenKes RI No 1239/MenKes/SK/XI/2001 sebagai dasar hukum praktik keperawatan disajikan dalam tabel 3.

Dari tabel 3 diketahui hasil uji statistik chi-square yaitu nilai rata-rata untuk perawat (Mean =1,96) dengan Standar Defiasi $=0,20$ yang menjelaskan bahwa sebagian besar responden memiliki persepsi yang benar yaitu dengan signifikansi $(p)=0,000$, sedangkan pegawai pemda menunjukan nilai rata-rata (Mean $=1,80)$, Standar Defiasi $=0,40$ yang menjelaskan bahwa sebagian besar responden memiliki persepsi yang benar yaitu dengan signifikansi $(p)=0,003$.

\section{Persepsi Perawat}

Bahwa perawat merupakan tenaga kesehatan yang dominan dalam sistem pelayanan kesehatan kepada masyarakat. Hal ini sesuai dengan pemahaman pengertian tenaga kesehatan yang tercantum dalam ketentuan umum undang-undang kesehatan bahwa tenaga kesehatan adalah setiap orang yang mengabdikan diri dalam bidang kesehatan serta memiliki pengetahuan dan ketrampilan melalui pendidikan di bidang kesehatan yang untuk jenis tertentu memerlukan kewenangan untuk melakukan upaya kesehatan. Dalam upaya peningkatan kesehatan di masyarakat, kalangan kesehatan harus tetap menyadari bahwa dalam menjalankan profesi keperawatan mereka tidak saja bertangung jawab terhadap kesehatan pasien tetapi juga bertanggung jawab di bidang hukum (legal responsibility) dari pelayanan yang diberikan (Yusuf, 1999).

Berdasarkan teori persepsi, yaitu suatu penilaian bagaimana kita mengintegrasikan sensasi ke dalam penghayatan obyek, dan bagaimana kita selanjutnya menggunakan penghayatan tersebut untuk mengenali dunia (Alkinson, 1993). Persepsi adalah daya mengenal barang, kualitas atau hubungan serta perbedaan antara hal ini melalui proses mengamati, mengetahui dan mengartikan setelah panca indranya mendapat rangsang (Maramis, 1994).

Bila perawat sebagaian besar memberikan persepsi yang benar terhadap berlakunya KepMenKes RI No 1239/ MenKes/SK/XI/2001 sebagai dasar hukum praktik keperawatan, sesuai dengan kenyataan di lapangan penelitian ini karena sesuai dengan peran dan fungsi perawat profesional dalam menyikapi permasalahan keperawatan dengan penuh tanggung jawab, memiliki motivasi yang tinggi dan terus menerus meningkatkan diri sesuai dengan ilmu pengetahuan dan teknologi kesehatan, berperilaku sopan dalam memberikan pelayanan dan memiliki pengalaman sesuai dengan perkembangan. Jika perawat dalam memberikan persepsi yang salah di penelitian ini dapat disimpulkan bahwa perawat kurang mengetahui peran dan fungsi perawat, selalu bekerja berdasarkan pada pengalaman masa lalu yang salah dan tidak mau mengembangkan diri dalam ilmu pengetahuan. 
Tabel 3. Perbandingan persepsi perawat dan pegawai pemda terhadap berlakunya KepMenKes RI No 1239/MenKes/SK/XI/2001 sebagai dasar hukum praktik keperawatan.

\begin{tabular}{|c|c|c|c|}
\hline Pernyataan & Perawat & Pegawai pemda & Total \\
\hline Benar & $24(96 \%)$ & $20(80 \%)$ & 25 responden $(100 \%)$ \\
\hline Salah & $1(4 \%)$ & $5(20 \%)$ & 25 responden $(100 \%)$ \\
\hline & $\begin{array}{c}\text { Mean }=1,96 \\
\text { SD }=0,20 \\
\text { Signifikansi }(p)=0,000\end{array}$ & $\begin{array}{c}\text { Mean }=1,80 \\
\text { SD }=0,40 \\
\text { Signifikansi }(p)=0,003\end{array}$ & \\
\hline
\end{tabular}

Hal ini kemungkinan dipengaruhi oleh mayoritas responden yang bekerja di rumah sakit, dimana perawat pada umumnya dalam menjalankan pekerjaan di rumah sakit cenderung rutin dan menganggap apa yang dilakukan selain merupakan tanggung jawab rumah sakit, termasuk juga tanggung jawab perawat jika ada kesalahan atau kelalaian sehingga ini menimbulkan persepsi akan ada dan pentingnya perlindungan hukum. Rumah sakit merupakan tempat pelayanan kesehatan yang komprehensif dan bersifat definitif,sehingga dalam proses pemberian pelayanan akan muncul berbagai masalah biopsokisosial dan spritual baik dari pemberi jasa maupun penerima jasa pelayanan kesehatan. Faktor rutinitas tersebut memberikan kesan walaupun persyaratan yang dimiliki oleh perawat belum memenuhi syarat berlakunya KepMenKes RI No 1239/ MenKes/SK/XI/2001 sebagai dasar hukum praktik keperawatan, perawat mulai merasa terlindungi, merasa terayomi yang berkaitan dengan pelaksanaan praktik keperawatan perorangan, kelompok maupun di rumah sakit yang umumnya pelayanan bersifat preventif, promotif, kuratif dan rehabilitatif, sehingga tingkat persepsi terhadap KepMenKes tersebut sangat tinggi.

\section{Persepsi Pegawai Pemerintah Daerah}

Beberapa pegawai yang masih memberikan persepsi yang salah tentang KepMenKes RI No 1239/MenKes/SK/XI/ 2001 sebagai dasar hukum praktik keperawatan. Hal ini disebabkan karena kurangnya informasi dan sosialisasi terhadap keberadaan KepMenKes RI No 1239/ MenKes/SK/XI/2001 tersebut. Manusia dalam mengembangkan persepsinya disebabkan oleh dua hal, pertama bahwa manusia mempunyai bahasa yang mampu mengkomunikasikan informasi dan jalan fikiran yang melatarbelakangi informasi tersebut, kedua bahwa manusia mempunyai kemampuan berfikir manurut alur kerangka fikir tertentu (Pitono, 2000).

Berdasarkan teori persepsi bahwa persepsi adalah pengalaman tentang obyek, peristiwa, atau hubungan-hubungan yang diperoleh dengan menyimpulkan informasi dan menafsirkan pesan (Rakhmad, 2000). Persepsi kita tentang orang lain dibentuk oleh asumsi kita tentang orang dan oleh situasi yang kita hadapi (Charles, 1997). Maka dapat disimpulkan bahwa persepsi merupakan stimulus sensori terhadap suatu obyek kemudian direspon melalui proses mengamati, mengetahui, mengartikan, serta menyimpulkan/menafsirkan, obyek tersebut untuk disikapi.

Pengamatan peneliti terhadap pegawai pemerintah daerah dalam mempersepsikan KepMenKes RI No 1239/MenKes/SK/XI/ 2001 sebagai dasar hukum praktik keperawatan, sebagaian besar menyatakan bahwa persepsi yang benar tentang mayoritas pegawai pemerintah daerah yang dijadikan responden mempunyai latar belakang pendidikan S1 (strata satu). semakin tinggi tingkat pendidikan seorang makin mudah untuk menerima informasi dan mepercepat persepsi seseorang terhadap salah satu obyek. 
Walaupun ada beberapa responden dari pegawai pemerintah daerah yang memberikan persepsi yang salah dikarenakan kurangnya pemahaman terhadap KepMenKes RI No 1239/MenKes/SK/XI/ 2001 sebagai dasar hukum praktik keperawatan. Selain itu juga disebabkan karena keterbatasan kuisioner yang digunakan masih kurang bisa mengukur persepsi yang sebenarnya karena kuisioner yang dibuat oleh peneliti tidak dilakukan uji validitas dan reliabilitasnya. Bisa juga hal ini disebabkan karena KepMenKes tersebut baru keluar pada tahun 2001 sehingga pegawai pemerintah daerah belum mendapatkan informasi yang jelas tentang KepMenKes tersebut. Kebanyakan responden yang khususnya dari pegawai pemerintah daerah hanya berpatokan pada pengalaman yang merupakan suatu sumber pengetahuan untuk mengungkapkan persepsi terhadap salah satu obyek yang diterimanya, Oleh karena itu pengalaman pribadipun dapat digunakan sebagai upaya memperoleh pendapat yang sesuai dengan kenyataan yang pernah dialaminya.

\section{Persepsi Perawat Dengan Pegawai Pemerintah Daerah}

Dengan diberlakukannya KepMenKes No RI 1239/MenKes/SK/XI/2001 sebagai dasar hukum praktik keperawatan, dimana kebijakan ini salah satunya adalah untuk melindungi profesi perawat dalam menjalankan praktik keperawatan. Maka diperlukan kesamaan persepsi dalam jajaran tenaga keperawatan khususnya yang terkait dengan praktik keperawatan dan jajaran profesi lain seperti pegawai pemerintah daerah pada umumnya guna mendukung jalanya proses profesionalisme di bidang keperawatan.

Teori persepsi menurut William James mengatakan persepsi merupakan pengalaman yang terbentuk berupa data-data yang didapat melalui panca indera hasil pengolahan otak dan ingatan. Dikatakan selanjutnya persepsi dihayati melalui ilusi, mispersepsi, trik atau tipuan dan bukan salah tanggapan (Widayatun, 1999).

Berdasarkan hasil penelitian dapat dijelaskan bahwa seluruh perawat dan pegawai pemerintah daerah dapat memberikan persepsi yang benar dengan hasil yang signifikan, walaupun ada sebagaian kecil yang masih mepersepsikan pernyataanya yang salah terkait dengan diberlakukannya KepMenKes RI No 1239/MenKes/SK/XI/ 2001 sebagai dasar hukum praktik keperawatan. Sehubungan dengan hal tersebut profesi perawat dengan profesi pegawai pemerintah daerah jelas mempunyai perbedaan dalam penerapan disiplin ilmu yang berpengaruh terhadap cara pandang atau persepsi pada salah satu obyek.

\section{KESIMPULAN DAN SARAN}

Berdasarkan pembahasan disimpulkan bahwa sebagian besar perawat (96\%) menyatakan persepsi yang benar terhadap diberlakukannya KepMenKes RI No 1239/ MenKes/SK/XI/2001 sebagai dasar hukum praktik keperawatan. Sebanyak $84 \%$ pegawai pemerintah daerah menyatakan persepsi yang benar terhadap diberlakukannya KepMenKes RI No 1239/MenKes/SK/XI/ 2001 sebagai dasar hukum praktik keperawatan. Secara kualitas tidak ada perbedaan persepsi antara perawat dengan pegawai pemerintah daerah terkait dengan diberlakukannya KepMenKes RI No 1239/ MenKes/SK/XI/2001 sebagai dasar hukum praktik keperawatan.

Saran yang dapat diberikan yaitu sosialisasi tentang KepMenKes RI No 1239/ MenKes/SK/XI/2001 sebagai dasar hukum praktik keperawatan oleh pengurus organisasi profesi PPNI Kabupaten Maluku Tengah perlu ditingkatkan ke semua instansi baik pelayanan maupun pendidikan sehingga seluruh perawat maupun instansi-instansi terkait mamahami tentang KepMenKes RI 
No 1239/MenKes/SK/XI/2001. Hal ini dapat dilakukan pada setiap pertemuan rutin anggota maupun dengan melalui seminar. Meningkatkan kesadaran perawat untuk memahami dan memiliki SIP, SIK dan SIPP sebelum menjalani praktik keperawatan. Mengembangkan penelitian lebih lanjut terutama terkait dengan dampak KepMenKes RI No 1239/MenKes/SK/XI/2001, terhadap peran dan tanggung jawab perawat.

\section{DAFTAR PUSTAKA}

Amirin, T.M. 1984. Pokok-pokok Teori Sistem. Jakarta: CV Rajawali.

Benyamin, L. 1989. Perawat, Citra, Peran dan Fungsi. Yogyakarta: Penerbit Kanisius.

David, Mc.C. 1996. Azas-Azas Penelitian Behavioral. Jakarta: Penerbit Erlangga.

DepKes RI. 2001. Peraturan Menteri Kesehatan Republik Indonesia No 1239/ MENKES/SK/XI/2001. Jakarta.

Dempsey, P.A., Dempsey, A.D. 1996. Nursing Research Text and Oprations Managemen Manufactoring and Nonmanufactoring. 4th edition. New York: Random House.

Gillkies, D.A. 1996. Nursing Management a System Approach. The W.B. Saunders Company.

Hasibuan, M. 2000. Manajemen Sumber Daya Manusia. Edisi revisi. Jakarta: Bumi Aksara.

Koeswadji, H.H. 1996. Undang-Undang No.23 tahun 1992 Tentang Kesehatan: Azas-Azas dan Permasalahan dalam Implementasinya. Bandung: PT Citra Aditya Bakti.

Koeswadji, H.H. 1998. Hukum Kedokteran. Bandung: PT Citra Aditya Bakti.

Kusnanto. 2004. Pengantar Profesi dan Praktik Keperawatan Profesional. Buku Satu. Jakarta: EGC.

Nursalam., Pariani, S. 2001. Pendekatan Praktis Metodologi Riset Keperawatan. Jakarta: Sagung Seto.
Nursalam. 2003. Konsep dan Penerapan Metodologi Penelitian Ilmu Keperawatan: Pedoman Skripsi, Tesis dan Instrumen Penelitian Keperawatan. Jakarta: Salemba Medika.

Nursalam. 2002. Manajemen Keperawatan: Aplikasi dalam Praktik Keperawatan Profesional. Jakarta: Salemba Medika.

Panitia Seminar Keperawatan. 2000. Kumpulan Makalah Seminar Keperawatan, Struktur Praktik Keperawatan dan Perkembangan Keperawatan Terkini. Surabaya.

Pitono, S. 2000. Filsafat Ilmu Kedokteran. Surabaya: Gramik.

Robert, P. 1995. Praktik Keperawatan Profesional, Konsep Dasar dan Hukum. Jakarta: EGC.

Saifudin. 1999. Sikap Manusia. Jakarta: Gramedia.

Sedarmayanti. 2001. Sumberdaya Manusia dan Produktifitas Kerja. Bandung: Mandar Maju.

Sulastomo. 2000. Manajemen Kesehatan. Jakartya: Gramedia.

Sioagian. 1990. Sistim Informasi untuk Pengambilan Keputusan. Jakarta: CV Hadji Mas Agung.

Thomas, R., Dye. 1978. Understanding Public Policy. 3rd edition. Englewood Cliffs: Engntide Inc. N.J. 07632.

Umar, H. 1999. Riset Sumber Daya Manusia dalam Organisasi. Jakarta: Gramedia Pustaka Utama.

UU RI No 23 Tahun 1992. Jakarta: Sinar Grafi.

UU Otonomi Daerah No 22 Tahun 1992. Jakarta: Graha Medika.

Wijono, D. 1999. Manajemen Mutu Pelayanan Kesehatan. Volume kedua. Surabaya: Airlangga Universitas Press.

Yoga, A.T., Yudanarso, D. 1996. Manajemen Pelayanan Penunjang Medik. Jakarta: Medika. 